deep central transverse depression at the posterior margin and a few short bristles in front. Antennæ slightly setose, sixjointed, the last joint cylindrical, rounded at the tip. Nuchal plate smooth, but uneven, with a slight central depression in front and an anterior marginal ridge. Dorsal plates covered with very fine shallow punctures. First dorsal segment with a distinct lateral marginal ridge; last dorsal segment arched, slightly compressed, its margin entire and not ridged; intermediate segments with the lateral extremities broad, rounded in front and rectangular behind, with a rough triangular excavation at the anterior lateral angle; the 10th and 11th segments broader than those before them. Black, shining, more or less marbled with dark testaceous. Length $\cdot 75$ inch, breadth $\cdot 4$ inch.

\title{
Loc. Dunedin.
}

Differs from S. De Lacyi (White, Ann. \& Mag. Nat. Hist. 3rd ser. iii. p. 406) in colour, in not being posteriorly attenuated, and in the head being much broader and shorter.

Obs. The types of all these species are preserved in the Otago Museum, Dunedin.

XVII._List of Lepidoptera recently collected by $M r$. Walter Davis in Peru, with Descriptions of a new Genus and several new Species. By Arthur G. Butler, F.L.S., F.Z.S., \&c.

THE interesting little collection of which this is an account was made by Mr. Davis at odd moments snatched from the prosecution of his study of the botany of the country.

Although the families Erycinidæ and Lycænidæ are unrepresented and only two species of Hesperiida have been obtained, the remaining families of the Rhopalocera are fairly represented, several rare and new species having been collected. Amongst the more striking forms may be mentioned the very scarce and beautiful Agrias sardanapalus, Catagramma Felderi, and two species of Callithea.

In order to render this enumeration as convenient as possible for reference, I have followed the arrangement adopted in Mr. Druce's List of Peruvian Butterflies in the 'Zoological Proceedings' for 1876. 


\section{RHOPALOCERA.}

\section{Nymphalidæ.}

$$
\text { DANAINA, Bates. }
$$

Mechanitis, Fabr.

1. Mechanitis egaënsis, var.

Mechanitis egaënsis, Bates, Trans. Linn. Soc. xxiii. p. 531, pl. 56. fig. $7 a$ (1862).

Ucayali.

One example, differing from Bates's figure in the narrower zigzag band of primaries.

Leucothyris, Butler and Druce (Ithomia, pt., Druce).

2. Leucothyris astrea.

Papilio astrea, Cramer, Pap. Exot. i. pl. 22. D (1775).

Ucayali.

3. Leucothyris perspicua.

Leucothyris perspicua, Butler, Trans. Ent. Soc. (1877).

Ucayali.

Melinea, Hübner.

\section{Melincea phasiana.}

Melinea phasiana, Butler, Trans. Ent. Soe. 1870, p. 489.

$\delta$ ․ Ucayali.

Morphine, Butler.

Morpho, Fabricius.

5. Morpho caruleus.

Arcuatus carulens, Perry, Arcana (1811).

Pozzuzo (October 1876).

\section{Morpho alexandrovna.}

Marpho alexandrovna, Druce, Trans. Ent. Soc. 1874, p. 155.

Ucayali. 


\author{
Brassoline, Bates. \\ Opsiphanes, Westwood.
}

7. Opsiphanes tamarindi.

Opsiphanes tamarindi, Felder, Wien. ent. Monatschr. v. p. 111. n. 107 (1861).

Pozzuzo.

Only one male of this species was obtained.

\author{
Acratine, Bates. \\ Actinote, Hübner (Acrca, pt., Druce).
}

8. Actinote sodalis, n. sp.

Allied to A amida, but the basal half (almost to external angle) of primaries rose-red ; the subapical band shorter, more oblique, and considerably narrower; secondaries jet-black to the base; abdomen spotted with orange; primaries below with the red areas precisely as above, the band being coloured like the basal area, the ground-colour yellowish instead of reddish, with the veins black. Expanse of wings 2 inches 2 lines.

Ucayali.

A. sodalis is a very distinct species allied to A. amida, griseata, callianira, and one or two other named forms; but it differs considerably from all of them. Mr. Davis obtained eight examples.

\title{
HELICONINE, Bates.
}

HeLiconius, Latreille.

9. Heliconius doris.

Papilio doris, Linnæus, Mant. Plant. p. 536 (1771)

Ucayali.

\section{Heliconius estrella.}

Heliconius estrella, Bates, Trans. Linn. Soc. xxiii. p. 560 (1862).

Ucayali.

A slight variety, the yellow band of primaries being rather wider th an usual, and placed rather further from the apex; in these respects it tends to approach $H$. Bartletti, which, if the extreme variability of this genus be unquestionable, should be considered a modification of H. estrella. Is it the 
form described by Felder as $\boldsymbol{H}$. aglaope? The description of the latter agrees better with $H$, estrella than with H. thelxiope,

Eueides, Hübner,

11. Eueides aliphera.

Cethosia aliphera, Godart, Enc. Méth, ix. p. 246 (1819),

Ueayali,

NyMPhaLine, Bates.

Colænis, Hübner.

12. Colcenis dido.

Papilio dido, Linnæus, Syst. Nat. i. 2, p. 782 (1767); Clerck, Icones, pl. 30. f. 2 (1764).

Rio Mairo (17th October, 1876).

13. Colcenis julia.

Papilio julia, Fabricius, Syst. Ent. p. 509 (1775),

Ucayali

14. Colcenis delila,

Papilio delila, Fabricius, Syst. Ent. p. 510 (1775).

Ucayali,

Eresia, Boisduval.

15. Eresia heliconoides, n. sp.

Wings above black-brown; primaries with two or three streaks at the base, and a broad patch just beyond the end of the cell, deeply incised upon the median nervure, rosered; body black: wings below brown, nervures and folds black: primaries with a cuneiform basal patch not reaching the subcostal vein, but divided by the median vein, reddish tawny; a broad red patch just beyond the end of the cell as above, but not incised upon the median nervure; secondaries reddish towards the base, yellowish at apex; pectus spotted with creamy yellowish. Expanse of wings 2 inches 2 lines.

Ucayali,

Evidently a mimic of Actinote sodalis, but more like some species of Heliconius of the H. elimcea group. It is allied to $E$. acrceina, but differs in the coloration of the secondaries and the base of the primaries. Two examples were obtained. 
16. Eresia nauplius.

Papilio nauplius, Linnæus, Mus. Lud. Ulr. p. 309 (1764).

Ucayali.

Eunica, Hübner.

17. Eunica bechina.

Cybdelis bechina, Hewitson, Exot. Butt, i. Cybd. pl. 2. f. 10 (1852). Ucayali,

18. Eunica pomona.

Faunia pomona, Felder, Reise der Nov. Lep. iii. pl. 52. figs. 11, 12 (1867).

Rio Mairo.

19. Eunica amelia.

Papilio amelia, Cramer, Pap. Exot. ii. pl. 136. B, C (1779).

Ucayali.

Epicalia, Westwood.

20. Epicalia acontius.

Papilio acontius, Linnæus, Mant. Plant. p. 537 (1771).

Ucayali.

Nica, Hübner.

21. Nica sylvestris.

Nica sylvestris, Bates, Journ. Entom. ii. p. 204 (1864).

Ucayali.

Eủbagis, Boisduval.

22. Eubagis cerata.

Eubagis cerata, Butler, Trans. Ent. Soc. 1877.

Ucayali.

Callicore, Hübner.

23. Callicore clymena.

Papilio clymena, Cramer, Pap. Exot. i. pl. 24. E, F (1775).

Callicore neglecta, Salvin, Ann. Nat. Hist. ser. 4 , vol. iv. p. 176 (1869).

Rio Mairo. 
The form called $C$. neglecta differs in an extremely variable character; so that I have been unable to consider it distinct.

24. Caliicore lidwina.

Callicore lidwina, Felder, Wien. ent. Monatschr. vi. p. 114 (1862).

Pozzuzo.

\section{Catagramma, Boisduval.}

\section{Catagramma Felderi.}

Catagramma Felderi, Hewitson, Exot. Butt. iii. Cat. pl. 10. figs. 68, 69 (1864) ; iv. Cat. pl. 12. f. 96 (1868).

Pozzuzo.

26. Catagramma excelsior, var.

Catagramma excelsior, Hewitson, Exot. Butt. ii. Cat. pl. 7. figs. 49, 50 (1858).

Morado (October 1876).

Mr. Davis states that this is rare; he only obtained one example, which differs from the typical form in the darker and narrower orange belt of primaries. Hewitson's second representation of C. excelsior is evidently a distinct thing; I cannot imagine why nobody has named it. I would propose that it be called $C$. inferior.

\section{Catagramma peristera.}

Catagramma peristera, Hewitson, Exot. Butt. i. Cat. pl. 2. figs. 15-17 (1853).

Ucayali.

28. Catagramma hystaspes.

Papilio hystaspes, Fabricius, Spec. Ins. ii. p. 57 (1781).

Ucayali.

\section{Catagramma cynosura.}

Papitio cynosura, Doubleday and Hewitson, Gen. D. Lep. pl. 28 . fig. 2 (1847).

Rio Mairo.

Callithea, Boisduval.

30. Callithea Degandii.

Callithea Degandii, Hewitson, Exot. Butt. ii. Call. pl. 2. figs. 6-8 (1858).

Puerto del Mairo (October 17, 1876).

Seven examples of this rare species were obtained. 


\section{Callithea Davisii, n. sp.}

Callithea Markii (part), Hewitscn, Exot. Butt. ii. pl. xxxii. fig. 5 (1857).

Ucayali.

This species, which I have only seen from Peru, is certainly distinct from the Ega form called C. Markii. We have long had two examples (from Peru) in the Museum; Mr. Davis has brought three others; and I have seen specimens in various private collections. The species of Callithea being rarely seen, Mr. Davis made a point of obtaining as many examples as he could.

\section{Pandora, Westwood.}

32. Pandora prola.

Pandora prola, Doubleday and Hewitson, Gen. Diurn. Lepid.pl. 43. f. 5 (1850).

Pozzuzo.

Only one example of this fine species was obtained.

Ageronia, Hübner.

33. Ageronia amphinome.

Papilio amphinome, Linnæus, Syst. Nat. i. 2, p. 779 (1766).

Pozzuzo.

Megalura, Blanchard (Timetes, Druce).

34. Megalura norica.

Timetes norica, Hewitson, Exot. Butt. i. Tim. pl. i. figs. 3, 4 (1852).

Ucayali.

35. Megalura crethon.

Papilio crethon, Fabricius, Gen. Ins. p. 252 (1777).

Ucayali.

\section{Megalura hermione.}

Timetes hermione, Felder, Wien. ent. Monatschr. v. p. 97 (1861).

Sarayacu.

\section{Marpesia, Hübner.}

37. Marpesia peleus.

Papilio peleus, Sulzer, Gesch. Ins. pl. 13. fig. 4 (1776).

Rio Mairo (October). 
VICTORINA, Blanchard.

38. Victorina sulpitia.

Papilio sulpitia, Cramer, Pap. Exot. iv. pl. 328. A, B (1782).

Ucayali.

\section{Heterochroa, Boisduval.}

39. Heterochroa Davisii, n. sp.

Allied to $H$. erotia, but smaller, with more falcate primaries; the orange band not united to costa externally, the third spot being absent; the outer margin of the band also not angulated in the same way between the first and second median branches, but narrowing gradually; no red spot above anal angle: underside altogether duller, the bands pale brown, with dark brown margins; the submarginal spots greyish; the disk of secondaries occupied by a broad brown band, through the centre of which runs a blackish stripe, and bordered with reddish brown; two external series of pale spots as in primaries, the outer series white and lunular. Expanse of wings 2 inches 5 lines.

Ucayali.

Also allied to Heterochroa urraca (which, I think, may possibly be $H$. erotia $\delta$ ), but differing in the same particulars.

Apatura, Fabricius.

40. Apatura griseldis.

Apatura griseldis, Felder, Wien. ent. Monatschr. vi. p. 117 (1862).

Ucayali.

\section{Apatura selina.}

Apatura selina, Bates, Journ. Entom. ii. p. 334 (1865).

Ucayali.

Aganisthos, Boisduval.

42. Aganisthos odius.

Papilio odius, Fabricius, Syst. Ent. p. 457. n. 60 (1775).

Rio Mairo.

43. Aganisthos acheronta.

Papilio acheronta, Fabricius, Syst. Ent, p. 501. n. 249 (1775).

Ucayali. 
Prepona, Boisduval.

44. Prepona antimache.

Morpho antimache, Hübner, Verz. bek. Schmett. p. 49 (1816).

Ucayali.

Agrias, Doubleday.

45. Agrias sardanapalus.

Agrias sardanapalus, Bates, Proc. Ent. Soc. ser. 2, vol. v. p. 111 (1860).

Cashiboya, elevation 550 feet (November 1876).

One very fair example of this species was obtained.

\section{Megistanis, Westwood.}

46. Megistanis deucation.

Megistanis deucalion, Felder, Wien. ent. Monatschr. iv. p. 238 (1860\%.

Ucayali.

There are no representatives in the collection of the families Erycinidæ and Lycænidæ; probably they were disregarded on account of their insignificant size.

\section{Papilionidæ.}

\section{Pierine, Bates. \\ Catasticta, Butler.}

47. Catasticta corcyra.

Euterpe corcyra, Felder, Wien. ent. Monatschr. iii. p. 327 (1859);

Reise der Nov. Lep. ii. pl. 23. f. 8 (1865).

Ucayali.

Evidently not an uncommon species in Peru.

Rhodocera, Boisduval.

48. Rhodocera menippe.

Mancipium fidelis menippe, Hübner, Samml, exot. Schmett. (180616).

Rio Mairo (October).

Very abundant. 
Callidryas, Boisduval.

49. Callidryas philea.

Papilio philea, Linnæus, Syst. Nat. i. 2, p. 764 (1776).

Ucayali.

Рнавis, Hübner.

50. Phobis hersitia.

Papilio hersilia, Cramer, Pap. Exot. ii. pl. 173. C, D (1779).

Ucayali.

51. Phoebis argante.

Papilio argante, Fabricius, Syst. Ent. p. 470 (1775).

Ucayali.

52. Phobis trite.

Papilio trite, Linnæus, Syst. Nat. i. 2, p. 763 (1766).

Ucayali.

Aphrissa, Butler.

53. Aphrissa statira.

Papilio statira, Cramer, Pap. Exot. ii. pl. 120. C, D (1779).

Rio Mairo.

Pieris, Boisduval.

54. Pieris demophile.

Papilio demophile, Linnæus, Syst. Nat. i. 2, p. 761 (1766).

Rio Mairo (October 18, 1876).

55. Pieris phaloë.

Pieris phaloë, Godart, Enc. Méth. ix. p. 156 (1819).

Ucayali.

Appias, Hübner.

56. Appias margarita.

Mylothris margarita, Hübner, Samml. exot. Schmett. (1816-41). Rio Mairo (October 18, 1876). 
Daptonura, Butler.

57. Daptonura peruviana.

Pieris peruviana, Lucas, Rev. Zool. p. 327 (1852).

Ucayali.

Dismorphia, Hübner.

58. Dismorphia theugenis.

Leptalis theugenis, Doubleday, Ann. Nat. Hist. ser. 2, vol. i. p. 124 (1848).

Ucayali.

$$
\begin{aligned}
& \text { Papilionine, Bates. } \\
& \text { Papilio, Linn. } \\
& \text { 59. Papilio crassus. }
\end{aligned}
$$

Papilio crassus, Cramer, Pap. Exot. ii. pl. 112. C (1779).

Rio Mairo.

60. Papilio protesilaus.

Papilio protesilaus, Linnæus, Mus. Lud. Ulr. p. 209 (1764).

Ucayali.

\section{Papilio theramenes.}

Papilio theramenes, Felder, Wien. ent. Monatschr. v. p. 74 (1861).

Cayaria.

62. Papilio cinyras, var.

Papilio cinyras, Ménétriés, Cat. Mus. Petrop. Lep. ii. pl. 7. fig. 3 (1857).

Rio Mairo.

Agrees with the form occurring at Villa Nova.

\section{Hesperiidæ.}

Pyrrhopyga, Hübner.

63. Pyrrhopyga fluminis.

Pyrrhopyga fluminis, Butler, Cist. Ent. i. p. 176 (1873).

Ucayali. 


\section{Pyrrhopyga hospita, n. sp.}

Allied to $P$. zonara, but the bands of primaries rather narrower; the basi-internal area of secondaries occupied by a discoidal spot and three to four narrow divergent internomedian streaks of pale blue; the discal band widely separated from the internal streaks, continuous and slightly tapering to near the anal angle: body silvery pale blue, the thorax longitudinally striped and the abdomen transversely banded with black; head black, spotted with white. Expanse of wings 2 inches 7 lines.

Ucayali (several examples).

\section{Heterocera.}

\section{Zygænidæ.}

Euchromitne, Butler.

Histiæa, Walker.

65. Histicea proserpina.

Euchromia proserpina, Hübner, Zutr. exot. Schmett. figs. 221, 222.

Ucayali.

\section{Melameridæ.}

\section{Pachiosia, n. gen.}

Allied to Micropus, but with the subcostals of secondaries emitted together from the end of the cell, instead of from a well-marked footstalk; the discocellulars more angulated, the first median branch emitted nearer to the second. Type P. flaveolata, Cramer.

\section{Pachiosia flaveolata.}

Phalcena flaveolata, Cramer, Pap. Exot. i. pl. lxxxviii. C (1779).

Ucayali.

A very common and well-known species.

\section{Dioptidæ.}

\section{Śtenele, Walker.}

67. Stenele calida.

Stenele calida, Butler, Ill. Lep. Het. p. 56, pl. xix. fig. 3 (1877).

ITcayali. 


\section{Uraniidæ.}

Urania, Fabricius.

68. Urania leilus.

Papilio leilus, Linnæus, Syst. Nat. ii. 1, p. 750 (1766).

Rio Mairo; Pozzuzo.

\section{Nyctalemon, Dalman.}

69. Nyctalemon empedocles.

Papilio empedocles, Cramer, Pap. Exot. iii. pl. cxcix. A, B (1782).

Cayaria, Ucayali.

This species is readily distinguished from $N$. lunus by the pale central band being intersected by a brown stripe.

XVIII.-Notes on a Paper by R. H. Traquair, M.D., F.G.S., F.R.S., on the Structure of the Lower Jaw in Rhizodopsis and Rhizodus, in the 'Annals and Magazine of Natural History,' vol. xix. 4th ser. p. 299. By Thomas ÁtThey.

In the first volume of the fourth series of this magazine were published "Notes" on Rhizodopsis, by my late friend Mr. Albany Hancock and myself, in which the præmaxilla is described as a long, narrow, wedge-shaped bone, with a row of small teeth along the margin, and two laniaries-one large, the other small, the latter placed in front of the former and near to the symphysis.

Since then a large number of specimens of the cranium of Rhizodopsis, several showing the præmaxilla in situ, have been obtained from the black shale at Newsham.

From three of the largest of these the matrix has been carefully and entirely cleared away, so that all the bones can be well seen. In these specimens the maxilla and our præmaxilla evidently form the margin of the upper jaw, along which is placed a row of small teeth, with two laniaries, one smaller than the other and lying near to the symphysis, quite as in our description.

The outline and the outer surface of the mandible are also well defined, with the row of small teeth along its alveolar border interlocking with or being overlain by those of the maxilla and præmaxilla.

On upwards of half a dozen mandibles in my collection Ann. \& Mag. N. Hist. Ser. 4. Vol. xx. 


\section{$2 \mathrm{BHL}$ Biodiversity Heritage Library}

Butler, Arthur G. 1877. "XVII.-List of Lepidoptera recently collected by Mr. Walter Davis in Peru, with descriptions of a new genus and several new species." The Annals and magazine of natural history; zoology, botany, and geology 20, 117-129. https://doi.org/10.1080/00222937708682206.

View This Item Online: https://www.biodiversitylibrary.org/item/63588

DOI: https://doi.org/10.1080/00222937708682206

Permalink: $\underline{\text { https://www.biodiversitylibrary.org/partpdf/59736 }}$

\section{Holding Institution}

University of Toronto - Gerstein Science Information Centre

\section{Sponsored by}

University of Toronto

\section{Copyright \& Reuse}

Copyright Status: NOT_IN_COPYRIGHT

This document was created from content at the Biodiversity Heritage Library, the world's largest open access digital library for biodiversity literature and archives. Visit BHL at https://www.biodiversitylibrary.org. 